\title{
Benthic macrofaunal assemblage in seagrass-mangrove complex and adjacent ecosystems of Punang-Sari Estuary, Lawas, Sarawak, Malaysia
}

\author{
ABDULLA AL-ASIF ${ }^{1}$, HADI HAMLI ${ }^{1, v}$, ABU HENA MUSTAFA KAMAL ${ }^{2, \bullet v}$, MOHD HANAFI IDRIS ${ }^{2}$, \\ GEOFFERY JAMES GERUSU ${ }^{3}$, JOHAN BIN ISMAIL ${ }^{1}$, NURUL ULFAH KARIM ${ }^{2}$ \\ ${ }^{1}$ Department of Animal Science and Fishery, Faculty of Agriculture and Forestry, University of Putra Malaysia. J1. Nyabau, UPM Bintulu Sarawak \\ Campus, Bintulu 97008, Sarawak, Malaysia. Tel.: +60-86-855225, Fax.: +60-86-855388, `email: hadihamli@upm.edu.my \\ ${ }^{2}$ Faculty of Fisheries and Food Science, University of Malaysia Terengganu. Kuala Nerus 21030, Terengganu, Malaysia. \\ Tel.: +60-96-685027, Fax.: +60-96-684949, •vemail: a.hena@umt.edu.my \\ ${ }^{3}$ Department of Forestry Science, Faculty of Agriculture and Forestry, University of Putra Malaysia. Jl. Nyabau, UPM Bintulu Sarawak Campus, Bintulu \\ 97008, Sarawak, Malaysia
}

Manuscript received: 4 August 2020. Revision accepted: 12 September 2020.

\begin{abstract}
Al-Asif A, Hamli H, Abu Hena MK, Idris MH, Gerusu GJ, Ismail JB, Karim NU. 2020. Benthic macrofaunal assemblage in seagrass-mangrove complex and adjacent ecosystems of Punang-Sari Estuary, Lawas, Sarawak, Malaysia. Biodiversitas 21: 46064615. Present study dealt with the on faunal and in faunal assemblage from seagrass bed, mangrove area, and adjacent non-mangrove and seagrass (NMS) in Punang-Sari estuary, Lawas, Sarawak, Malaysia. Samples were collected from June to July 2019 using quadrates and handpicking from the outside the sampling area to know the real checklist of surface macrofauna in this area. A ten-meter transect line was settled in three habitat areas where sampling was performed by putting three quadrates $(0.35 \mathrm{~m} \times 0.35 \mathrm{~m})$. Epifauna and infauna samples were collected from inside the quadrate and sieved using $0.4 \mathrm{~mm}$ mesh size sieve. A total of 111 species of gastropod (87 species from 30 families), bivalve (18 species from 9 families), Polychaeta $(2$ species), echinoderms ( 1 species), and crustacean ( 3 species) were recorded during the study period. Seagrass meadows comprised most diverse and abundant faunal (50 species) assemblage followed by mangrove habitats (48 species), and NMS (20 species). The dendrogram revealed two significant habitats in the sampling site. PCA analysis revealed, seagrass habitat sheltered a higher number of species followed by mangrove and NMS area. Jaccard similarity index revealed seagrass and mangrove habitats $(0.42)$ contains the highest similar species amongst all habitats compared to mangrove and non-seagrass-mangrove area (0.26). Out of total species recorded (101), only ten species were reported as least concern, and 2 species hold deficient data status, and the rest are not evaluated. Bio-assemblage in seagrass habitat was found rich compared to other habitats, which could be useful for future ecological investigation and marine ranching.
\end{abstract}

Keywords: Checklist, ecology, IUCN red list, Malaysian Borneo, mollusk

\section{INTRODUCTION}

Mangrove and seagrass areas are widespread coastal and estuarine ecosystems found in tropical and subtropical latitudes (Saenger et al. 2012). Co-existence of these two unique coastal habitats could generate the most complex ecosystem on this planet (Fortes 1991). Tropical seagrass meadows and mangrove forests are outstanding examples to fight against climate change impacts and restore the natural habitat. These vegetated coastal environments are known as "Blue Carbon" ecosystem which provides foods and nursing amenities up to the juvenile stage for many marine creatures (Short et al. 2011; Abu Hena et al. 2017) There are 16 species of seagrasses in Malaysia (Bujang et al. 2018) and however, there are at least a total of 70 mangroves species from 28 families that are found in the coastal region of this country. Malaysian seagrassmangrove complex comprises plethora of macrofauna species. Macrofauna is the most widely studied benthic organisms, which are retained on $0.5 \mathrm{~mm}$ or $1.0 \mathrm{~mm}$ mesh sieve (Valenca and Santos 2013). They reside beneath the sediment surface in burrows and tubes. Thus, the bottom of the mangrove substratum habitats forms a wide array of macrobenthic organisms of various sizes and taxonomic categories. They play an essential role in the marine ecosystem and another ecosystem like aquaculture pond (Abu Hena et al. 2004) which includes mineralization, mixing of sediments and flux of oxygen into the sediment, cycling of organic matter, and assessing the quality of inland water (Esenowo and Ugwumba 2010). The previous investigation revealed the relations of macrobenthos on different estuarine (Ortegaa et al. 2018) habitats like mangroves (Hamli et al. 2015; Abu Hena et al. 2016; Idris et al. 2017a; Idris et al. 2017b), seagrass (Qingxi et al. 2017), saltmarsh (Rezek et al. 2017), lagoons (Chaouti et al. 2019) are very significant. Some of the previous studies reported the distribution and assemblage of macrofauna in different Malaysian states (Wong and Arshad 2011; Hamli et al. 2013; Singh and Baharin 2016; Halim et al. 2019) which do not represent information from the whole country. However, those investigations are conducted to reveal the specific regional and ecosystem-based status of macrofauna. 
The state of Sarawak is well known for being the part of Borneo, which is the most diverse biological hotspot on this planet. Although the status of macrobenthos in some ecosystems of Peninsular Malaysia had been previously reported, and a little number of macrobenthos studies were conducted in Sarawak estuary, mangrove, tidal marsh, seagrass bed (Hamli et al. 2013; $\mathrm{Ng}$ et al. 2017). Nonetheless, data on faunal assemblage in seagrassmangrove of Punang-Sari, Lawas estuary is limited. Therefore, this approach was initiated to observe the faunal assemblage in the seagrass-mangrove complex of PunangSari, Lawas, Sarawak, Malaysia. The findings of this research will provide the scientific evidence of number and diversity of benthic fauna available in Sarawak coast, Malaysia. The outcomes of this research can be led to take the decision for policymakers and scientists for further study and conservation approach of this site. Data gathered from this study will also be helpful for the local community towards sustainable harvesting of commercially important benthic fauna from this seagrass-mangrove habitat.

\section{MATERIALS AND METHODS}

\section{Description of the study area}

Punang-Sari estuary, Lawas, Sarawak, Malaysia lies $4^{\circ} 54^{\prime} 37.7^{\prime \prime} \mathrm{N}, 115^{\circ} 23^{\prime} 09.5^{\prime \prime} \mathrm{E}$ latitude and $4^{\circ} 55^{\prime} 27.9^{\prime \prime} \mathrm{N}$, $115^{\circ} 23^{\prime} 33.3^{\prime \prime E}$ longitude (Figure 1) which is the mouth of two rivers namely Punang and Sari which is flowing towards South China Sea and located $15 \mathrm{~km}$ from the nearest Lawas township. A complex ecosystem dynamics were found, which comprises, seagrass-mangrove, intertidal zone, oceanic attachment, terrestrial ecosystem and human habitat. Three different habitats were chosen to conduct the study (Table 1).

\section{Collection of samples}

Three representative sites, seagrass meadows, mangrove areas, and one without seagrass-mangroves area (NMS) at Punag-Sari estuary, Lawas were selected for the present investigation. Sampling was carried out from June to July 2019 during the low tide period. Transect line (10 m) was laid perpendicularly from the seaward margin into the seagrass bed, mangrove forest, and NMS area. Three quadrats $(0.35 \mathrm{~m} \times 0.35 \mathrm{~m})$ were fixed, covering all the zones of seagrass and mangroves (Mendoza et al. 2019). Onfauna and in-fauna $(10 \times 10 \times 5 \mathrm{~cm})$ samples were collected from inside the quadrate and sieved using $0.4 \mathrm{~mm}$ mesh size sieve then put into a plastic bag. To make the full species list of macrobenthos fauna available in Punag-Sari estuary, Lawas area. Samples were also collected from the intertidal beach area during low tide period to know the comprehensive checklist of the on fauna. Collected samples were preserved in an icebox and taken to the laboratory for documentation and species identification. The specimens were identified by using following taxonomical descriptions and keys, Poutiers (1998); Tan and Clements (2008); Chan (2009); Wong (2009); Cob et al. (2012); Hamli et al. (2013); Fairoz et al. (2018); Herbert et al. (2018). All taxonomic names were rechecked with WoRMS (2020). The global distribution and IUCN status were checked with IUCN (2020) and Sea Life Base (2020) websites.

Table 1. List of the sample collection location

\begin{tabular}{lll}
\hline \multicolumn{1}{c}{ Name of the habitat } & Short-form & \multicolumn{1}{c}{ Habitat } \\
\hline Seagrasses & Seagrass & Seagrass \\
Mangrove area & Ma & Mangrove \\
No mangrove-seagrass area & NMS & NMS \\
\hline
\end{tabular}

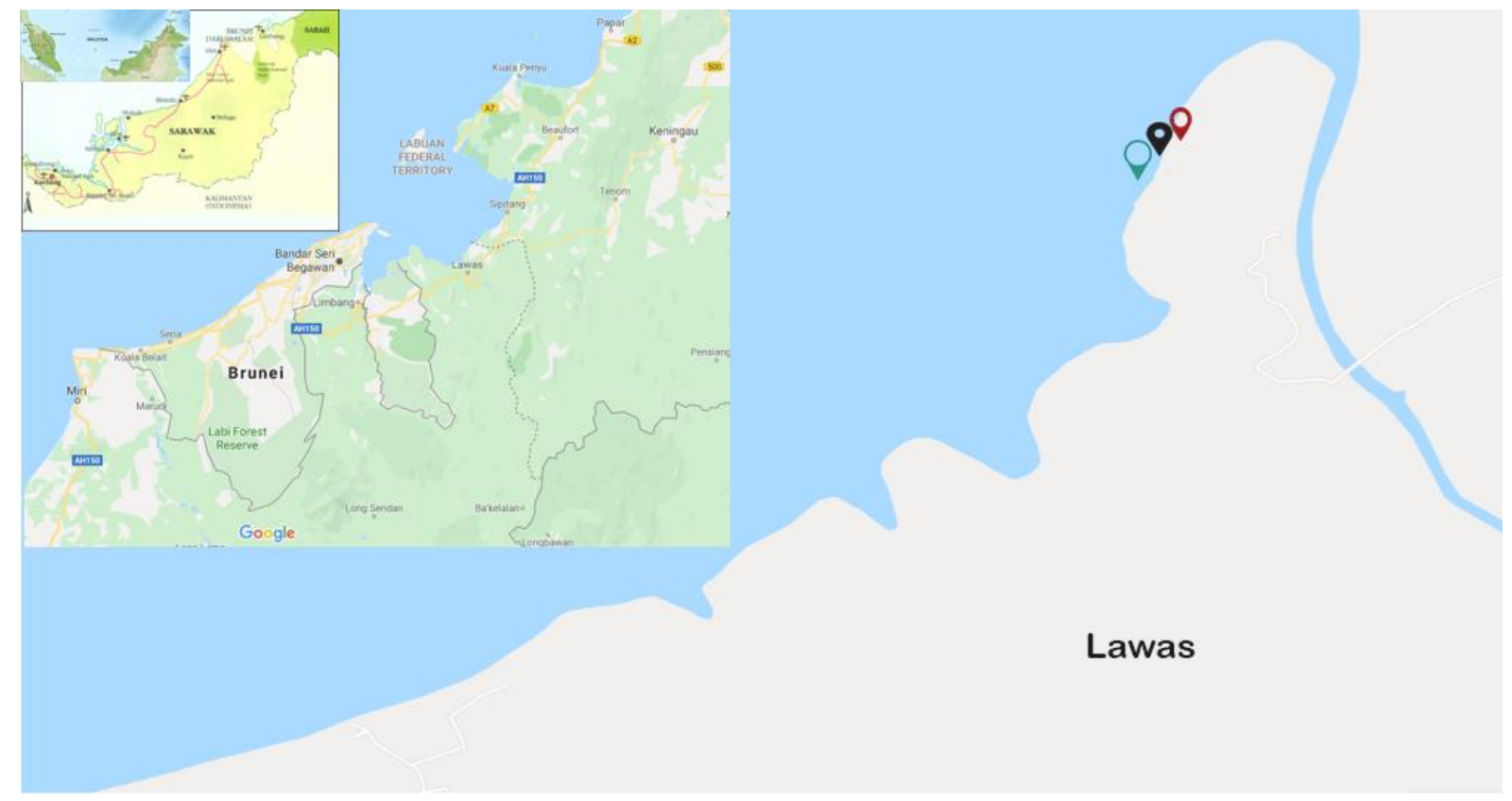

Figure 1. Study area location showing the sampling area at Lawas, Sarawak, Malaysia (red marked: mangrove, black marked: seagrass, and green marked: no mangrove-seagrass area) 


\section{Data analysis}

The cluster analysis and Principal Component Analysis (PCA) of similarity detection were done following paired group Euclidean cluster and Pearson (1901) methods, respectively. Jaccard similarity index was performed following Jaccard (1901) to the analysis of faunal similarity among habitats using PAST version 4.3. The one-way ANOVA and Tukey test were performed to know the significance of different habitat by using SAS 9.4. The IUCN red list status analysis was done using Microsoft Excel 2013.

\section{RESULTS AND DISCUSSION}

A total of 105 mollusk species comprising 87 gastropods sp., 18 bivalve sp., 1 species of echinoderm, 2 species of Polychaeta, and 3 species of crustacean recorded from the study area (Tables 2-4). Seagrass meadows comprised, 38 species of gastropods from 15 different families, 9 species of bivalves from 8 consecutive families, 2 species of Polychaeta from Pauroidea family. Mangrove habitat comprised a total of 40 species of gastropods from 18 families, 5 species of bivalves from 5 different families, 2 species of Polychaeta from Pauroidea family and 1 species of crustacean (Family: Portunidae). A total of 12 species of gastropod, 6 species of bivalve, and 2 species of Polychaeta recorded from NMS habitat.

\section{Gastropod}

Gastropod documented in the present study comprises 87 species from 30 families, in which 38 species from 14 different families were enlisted in seagrass meadows, 40 species of 18 families from mangrove habitat, and 12 species of five families were recorded in NMS area (Table 2). Cerithiidae is the most dominant family (based on individual numbers) in the study area. In this current study, the family Nassariidae had the highest number of individuals of species (13 species) followed by Neritidae (8 species), Potamididae (7 species), Trochidae (7 species), Muricidae (6 species), Naticidae (4 species), Strombidae (4 species), Ellobiidae (4 species), Melongenidae (4 species), Assimineidae (3 species), Cerithiidae (3 species), Fasciolariidae (3 species), Olividae (2 species), Pyramidellidae (2 species) and rest has 1 species from each family.

\section{Bivalve}

Totally 18 bivalves species from 9 families documented in the present study, in which 9 species of bivalves from 8 consecutive families from seagrass meadows, 5 species of bivalves from 5 different families from mangrove habitat, and 6 species of bivalves from 5 different families from NSM area (Table 3). Veneridae (6 species) was the most diverse family in the bivalve in terms of the number of species, followed by Arcidae (4 species), Tellinidae (2 species) and rest of the family has 1 species. Tellinidae was the most dominant family (134 individuals) in all habitat.

Table 2. Gastropods recorded from Punang-Sari Estuary, Lawas, Sarawak, Malaysia

\begin{tabular}{|c|c|c|c|c|c|c|c|c|c|}
\hline \multirow{2}{*}{ Family } & \multirow{2}{*}{ Species } & \multirow{2}{*}{$\begin{array}{l}\text { IUCN } \\
\text { status }\end{array}$} & \multicolumn{2}{|c|}{ Seagrass } & \multicolumn{2}{|c|}{ Mangrove } & \multicolumn{2}{|c|}{ NMS } & \multirow{2}{*}{$\begin{array}{l}\text { Out of } \\
\text { station }\end{array}$} \\
\hline & & & In & Epi & In & Epi & In & Epi & \\
\hline Architectonicidae & Architectonica $\mathrm{sp.}$ & $\mathrm{NE}$ & + & - & - & - & - & - & - \\
\hline \multirow[t]{3}{*}{ Assimineidae } & Optediceros breviculum & NE & - & + & + & + & - & - & - \\
\hline & Assiminea grayana & $\mathrm{LC}$ & - & - & + & + & - & - & - \\
\hline & Assiminea ovata & $\mathrm{LC}$ & - & - & + & + & - & - & - \\
\hline Batillariidae & Batillaria zonalis & NE & - & - & + & - & - & - & + \\
\hline \multirow[t]{2}{*}{ Buccinidae } & Solenosteira cancellaria & NE & + & + & - & - & - & - & + \\
\hline & Orania gaskelli & NE & - & - & - & - & - & - & + \\
\hline Cassidae & Semicassis granulata & NE & - & - & + & - & - & - & + \\
\hline \multirow[t]{3}{*}{ Cerithiidae } & Cerithium coralium & $\mathrm{LC}$ & + & + & + & + & - & - & + \\
\hline & Cerithium atratum & $\mathrm{NE}$ & + & + & + & + & + & + & + \\
\hline & Rhinoclavis kochi & NE & + & + & + & + & + & + & + \\
\hline Columbellidae & Parvanachis obesa & NE & + & + & - & + & - & - & + \\
\hline Cymatiidae & Gyrineum natator & NE & + & + & - & - & - & - & + \\
\hline \multirow[t]{4}{*}{ Ellobiidae } & Ellobium aurisjudae (sp.) & $\mathrm{LC}$ & - & - & - & - & - & - & + \\
\hline & Myosotella myosotis & $\mathrm{LC}$ & - & - & - & + & - & - & + \\
\hline & Cassidula nucleus & DD & - & - & - & - & - & - & + \\
\hline & Cassidula labrella & $\mathrm{LC}$ & - & - & - & - & - & - & + \\
\hline \multirow[t]{3}{*}{ Fasciolariidae } & Fusinus salisburyi & NE & - & - & - & - & - & - & + \\
\hline & Filifusus filamentosus & NE & - & - & - & - & - & - & + \\
\hline & Peristernia nassatula & NE & - & - & - & + & - & - & + \\
\hline Haminoeidae & Haloa natalensis & NE & + & + & + & & & & + \\
\hline Littorinidae & Littoraria intermedia & NE & - & - & - & - & - & - & + \\
\hline Mangeliidae & Eucithara marginelloides & NE & - & - & + & - & - & - & + \\
\hline
\end{tabular}




\begin{tabular}{|c|c|c|c|c|c|c|c|c|c|}
\hline \multirow[t]{4}{*}{ Melongenidae } & Volegalea cochlidium & $\mathrm{NE}$ & - & - & & + & - & - & + \\
\hline & Pugilina morio & NE & - & - & - & + & - & - & + \\
\hline & Pugilina tupiniquim & NE & - & - & - & + & - & - & - \\
\hline & Volema myristica & $\mathrm{NE}$ & - & - & - & - & - & - & + \\
\hline Mitridae & Mitra sp. & $\mathrm{NE}$ & - & - & - & - & - & - & + \\
\hline \multirow[t]{6}{*}{ Muricidae } & Rapana venosa & $\mathrm{NE}$ & - & - & - & - & - & - & + \\
\hline & Indothais lacera & $\mathrm{NE}$ & - & - & - & - & - & - & + \\
\hline & Indothais rufotincta & $\mathrm{NE}$ & - & - & - & - & - & - & + \\
\hline & Indothais malayensis & NE & - & - & - & - & - & - & + \\
\hline & Chicoreus capucinus & NE & - & - & - & - & - & - & + \\
\hline & Indothais javanica & NE & - & - & - & - & - & - & + \\
\hline \multirow[t]{13}{*}{ Nassariidae } & Nassarius livescens & NE & + & + & - & + & - & - & + \\
\hline & Nassarius venustus & NE & - & + & - & + & - & - & + \\
\hline & Nassarius albescens & NE & - & - & - & + & - & - & + \\
\hline & Nassarius stolatus & NE & - & - & - & - & - & - & + \\
\hline & Nassarius pullus & $\mathrm{NE}$ & + & + & - & + & - & - & + \\
\hline & Nassarius globosus & NE & + & + & - & - & - & - & + \\
\hline & Nassarius castus & NE & - & - & - & + & - & - & + \\
\hline & Nassarius kraussianus & NE & - & - & - & - & - & - & + \\
\hline & Nassarius reeveanus & NE & - & - & + & + & - & - & + \\
\hline & Phrontis polygonata & NE & - & - & - & - & - & - & + \\
\hline & Tritia cuvierii & $\mathrm{NE}$ & - & - & - & - & - & - & + \\
\hline & Nassarius foveolatus & NE & - & + & - & - & - & - & + \\
\hline & Nassarius niger & $\mathrm{NE}$ & + & + & - & + & - & - & + \\
\hline \multirow[t]{4}{*}{ Naticidae } & Naticarius stercusmuscarum & $\mathrm{NE}$ & - & - & + & - & - & - & + \\
\hline & Stigmaulax elenae & NE & - & - & + & - & - & - & + \\
\hline & Polinices hepaticus & NE & + & + & - & - & - & - & + \\
\hline & Polinices aurantius & $\mathrm{NE}$ & + & + & - & - & - & - & + \\
\hline \multirow[t]{8}{*}{ Neritidae } & Clithon oualaniense & $\mathrm{NE}$ & + & + & + & + & - & - & + \\
\hline & Clithon faba & $\mathrm{LC}$ & + & + & + & + & + & - & - \\
\hline & Nerita chamaeleon & $\mathrm{NE}$ & + & + & + & + & - & - & - \\
\hline & Vitta virginea & $\mathrm{LC}$ & + & + & - & - & + & - & + \\
\hline & Vittina coromandeliana & NE & + & + & - & - & - & - & + \\
\hline & Vitta zebra & NE & + & + & + & - & + & - & + \\
\hline & Nerita albicilla & NE & + & - & - & - & - & - & - \\
\hline & Neripteron violaceum & NE & + & - & - & - & + & - & - \\
\hline \multirow[t]{2}{*}{ Olividae } & Agaronia gibbosa & NE & - & - & - & - & - & - & + \\
\hline & Oliva tremulina & NE & - & - & - & - & - & - & + \\
\hline \multirow[t]{7}{*}{ Potamididae } & Terebralia palustris & DD & + & + & + & + & - & - & + \\
\hline & Telescopium telescopium & $\mathrm{LC}$ & - & - & - & + & - & - & + \\
\hline & Pirenella cingulata & NE & + & + & + & + & - & - & + \\
\hline & Cerithidea quoyii & NE & + & - & + & + & - & - & + \\
\hline & Cerithidea sp. & NE & - & - & + & + & - & - & + \\
\hline & Pirenella microptera & NE & + & + & + & + & + & - & + \\
\hline & Pirenella conica & $\mathrm{LC}$ & - & - & + & - & - & - & + \\
\hline \multirow[t]{2}{*}{ Pyramidellidae } & Otopleura auriscati & NE & - & - & - & - & - & - & + \\
\hline & Syrnola adamsi & NE & + & + & + & + & - & - & + \\
\hline Rissoinidae & Rissoina inca & NE & + & + & + & - & + & & + \\
\hline \multirow[t]{4}{*}{ Strombidae } & Laevistrombus canarium & NE & - & - & - & - & - & - & + \\
\hline & Doxander vittatus & NE & - & - & - & - & - & - & + \\
\hline & Laevistrombus turturella & NE & - & - & - & - & - & - & + \\
\hline & Canarium urceus & $\mathrm{NE}$ & - & - & - & - & - & - & + \\
\hline Succineidae & Oxyloma patentissimum & $\mathrm{NE}$ & - & - & - & - & - & - & + \\
\hline Thiaridae (FW) & Thiara sp. & $\mathrm{NE}$ & - & - & - & - & - & - & + \\
\hline \multirow[t]{7}{*}{ Trochidae } & Umbonium elegans & NE & + & + & + & - & - & + & + \\
\hline & Umbonium vestiarium & NE & + & + & + & - & + & - & + \\
\hline & Umbonium thomasi & NE & + & + & - & - & - & - & + \\
\hline & Umbonium eloiseae & $\mathrm{NE}$ & + & + & - & - & - & - & + \\
\hline & Umbonium moniliferum & $\mathrm{NE}$ & + & + & - & & + & - & + \\
\hline & Umbonium suturale & NE & + & + & - & - & + & - & + \\
\hline & Umbonium costatum & NE & + & + & - & - & - & - & + \\
\hline Turridae & Lophiotoma acuta & NE & - & - & - & - & - & - & + \\
\hline Turritellidae & Turritella terebra & NE & - & - & - & - & - & - & + \\
\hline Volutidae & Fulgoraria hamillei & $\mathrm{NE}$ & - & - & - & - & - & - & + \\
\hline
\end{tabular}


Table 3. Bivalves recorded from Punang-Sari Estuary, Lawas, Sarawak, Malaysia

\begin{tabular}{|c|c|c|c|c|c|c|c|c|c|}
\hline \multirow{2}{*}{ Family } & \multirow{2}{*}{ Species } & \multirow{2}{*}{$\begin{array}{l}\text { IUCN } \\
\text { status }\end{array}$} & \multicolumn{2}{|c|}{ Seagrass } & \multicolumn{2}{|c|}{ Mangrove } & \multicolumn{2}{|c|}{ NMS } & \multirow{2}{*}{$\begin{array}{l}\text { Out of } \\
\text { station }\end{array}$} \\
\hline & & & In & Epi & In & Epi & In & Epi & \\
\hline \multirow[t]{4}{*}{ Arcidae } & Anadara sp. & $\mathrm{NE}$ & + & - & - & - & - & - & + \\
\hline & Anadara antiquata & $\mathrm{NE}$ & - & - & - & - & - & - & + \\
\hline & Anadara kagoshimensis & NE & - & - & - & - & - & - & + \\
\hline & Anadara indica & NE & - & - & - & - & - & - & + \\
\hline Cardiidae & Parvicardium sp. & NE & + & & + & + & + & & + \\
\hline Crassatellidae & Bathytormus radiatus & NE & + & - & - & - & - & - & - \\
\hline Donacidae & Donax faba & $\mathrm{NE}$ & + & - & - & - & - & - & + \\
\hline Limidae & Ctenoides philippinarum & $\mathrm{NE}$ & + & + & + & + & + & + & + \\
\hline Lucinidae & Lepidolucina venusta & NE & + & + & + & + & + & - & - \\
\hline Solecurtidae & Azorinus coarctatus & NE & - & - & - & - & - & - & + \\
\hline \multirow[t]{2}{*}{ Tellinidae } & Tellina sp. (White) & NE & - & + & - & - & - & - & + \\
\hline & Eurytellina lineata & NE & + & + & + & + & + & - & + \\
\hline \multirow[t]{6}{*}{ Veneridae } & Callista erycina & $\mathrm{NE}$ & - & + & + & + & - & - & + \\
\hline & Meretrix lyrata & NE & - & - & - & - & + & - & + \\
\hline & Meretrix casta & NE & - & - & - & - & - & - & + \\
\hline & Meretrix lusoria & NE & - & - & - & - & + & - & + \\
\hline & Gafrarium pectinatum & $\mathrm{NE}$ & - & - & - & - & - & - & + \\
\hline & Placamen isabellina & $\mathrm{NE}$ & - & + & - & - & - & - & + \\
\hline
\end{tabular}

Note: +: Present; -: Absent; Global distribution of species is listed from literature cited, 1-234. NE= Not Evaluated; In refers Infauna and Epi refers epifauna found in habitats

Table 4. Starfish species recorded from Punang-Sari Estuary, Lawas, Sarawak, Malaysia

\begin{tabular}{|c|c|c|c|c|c|c|c|c|c|}
\hline \multirow{2}{*}{ Family } & \multirow{2}{*}{ Species } & \multirow{2}{*}{$\begin{array}{l}\text { IUCN } \\
\text { status } \\
\end{array}$} & \multicolumn{2}{|c|}{ Seagrass } & \multicolumn{2}{|c|}{ Mangrove } & \multicolumn{2}{|c|}{ NMS } & \multirow{2}{*}{$\begin{array}{l}\text { Out of } \\
\text { station }\end{array}$} \\
\hline & & & In & Epi & In & Epi & In & Epi & \\
\hline \multicolumn{10}{|l|}{ Starfish } \\
\hline Astropectinidae & Astropecten vappa & $\mathrm{NE}$ & - & - & - & - & - & - & + \\
\hline \multicolumn{10}{|l|}{ Polycheta } \\
\hline \multirow[t]{2}{*}{ Paguroidea } & Diogenes sp. & NE & + & + & + & + & + & + & + \\
\hline & Clibanarius longitarsus & $\mathrm{NE}$ & + & + & + & + & + & + & + \\
\hline \multicolumn{10}{|l|}{ Crustacean } \\
\hline Nereididae & Perinereis maindroni & $\mathrm{NE}$ & - & - & - & - & - & - & + \\
\hline \multirow{2}{*}{ Portunidae } & Nicon sp. & NE & - & - & - & - & - & - & + \\
\hline & Scylla sp. & $\mathrm{NE}$ & - & - & + & + & - & - & + \\
\hline
\end{tabular}

Note: +: Present; -: Absent; Global distribution of species is listed from literature cited, 1-234. NE= Not Evaluated; In refers to Infauna and Epi refers to epifauna found in habitats

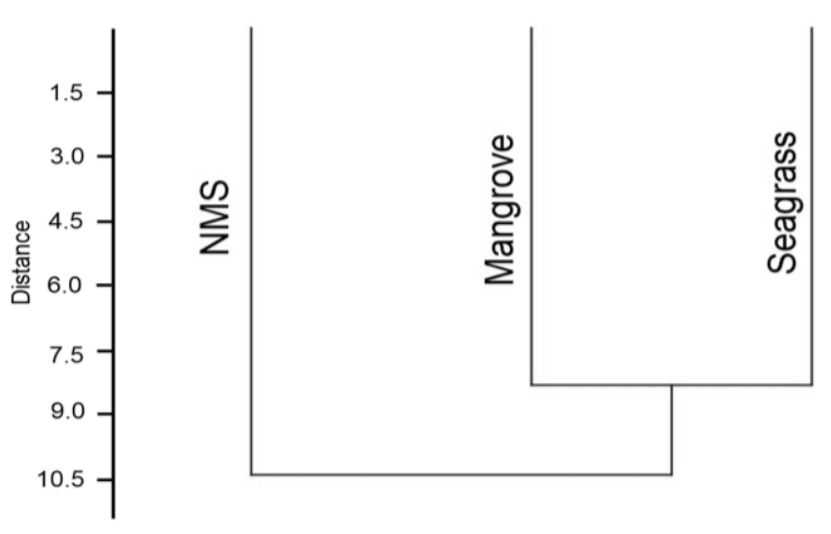

Figure 2. Dendrogram showing the macrobenthos diversity in different habitat of the study area

\section{Starfish, Polychaeta and Crustacean}

Only one echinoderm (starfish) species was found from the Astropectinidae family documented in NMS (no mangrove and seagrass) area. A total of 2 polychaeta species from Paguroidea family documented in the present study, and 2 species were equally dominant in all reported habitats. One crustacean species was found in the mangrove from Portunidae family (Table 4).

\section{Cluster analysis}

Cluster analysis of benthos density in three habitats revealed a clear inter-habitat grouping. The dendrogram presented the macrobenthos density of all three habitats were generally classified into two groups at the similarity level of 10.5 (Euclidean) based on the difference of habitats (Figure 2). 


\section{ANOVA of three habitats}

Seagrass habitat indicated significantly $(\mathrm{p}<0.01)$ rich in number of species (mean value: 1.1628) compared to mangrove (1.0465), and NMS (0.5349) habitat contains less number of species compare to seagrass habitat (Figure $3)$.

\section{Principal Component Analysis (PCA)}

Species (gastropod, bivalve, echinoderms, polychaetes and crustaceans) assemblage of amongst different habitats, there were three major groups formed, namely, seagrass, mangrove, and NMS (Figure 4). Where higher correlation factor of macrobenthos in seagrass meadow was found 0.97 , followed by Mangrove (0.88) and NMS (0.66) habitat in Punang-Sari, Lawas (Figure 5).

\section{Jaccard similarity index}

The Jaccard Similarity Index (JSI) revealed that the highest similarity was found in seagrass and mangrove habitat (0.42). The lowest similarity was found in NMS and mangrove habitat (0.26) (Figure 6).

\section{IUCN red list status}

It is revealed that most of the species (gastropod, bivalve, echinoderm, polychaete and crustacean) found in Punang-Sari-Lawas river estuary, Sarawak was not accessed by the IUCN red list authority. A total, $101 \mathrm{sp}$. is not evaluated globally which was found in Punang-SariLawas river estuary, Sarawak. Another, ten least concerned (LC) and two data deficient (DD) status species were also found in present study (Figure 7).

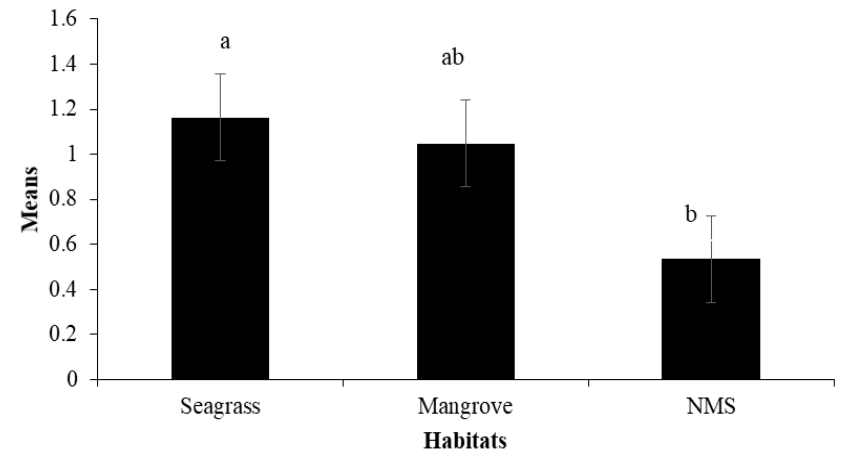

Figure 3. Seagrass habitat comprised significantly $(\mathrm{p}<0.01)$ higher number of species compared to other habitats

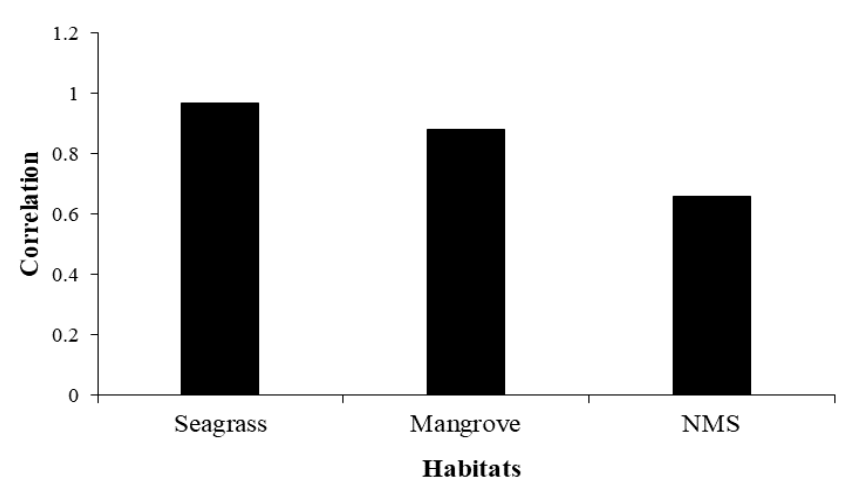

Figure 5. Correlation factor of macrobenthos density in different habitats of Punag-Sari-Lawas Estuary, Sarawak, Malaysia

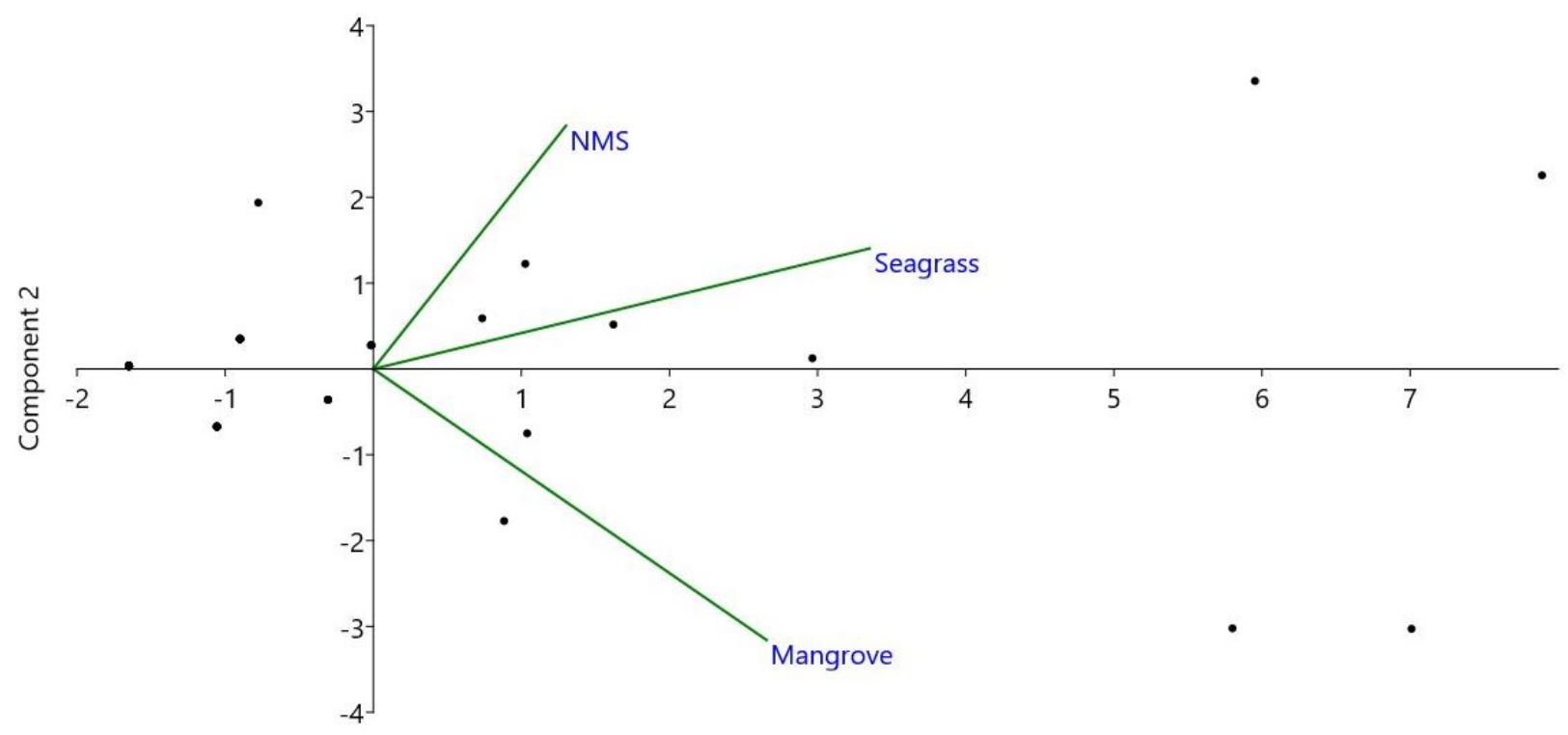

Component 1

Figure 4. PCA showing scatter plot for macrobenthos density in different habitats of Punag-Sari-Lawas Estuary, Sarawak, Malaysia 


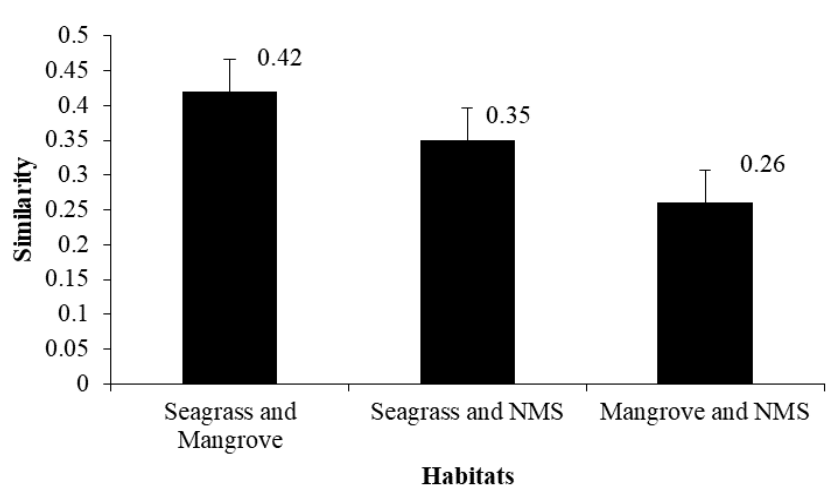

Figure 6. Jaccard Similarity Index of recorded macrobenthos among different habitats of Punang-Sari-Lawas River Estuary, Sarawak, Malaysia

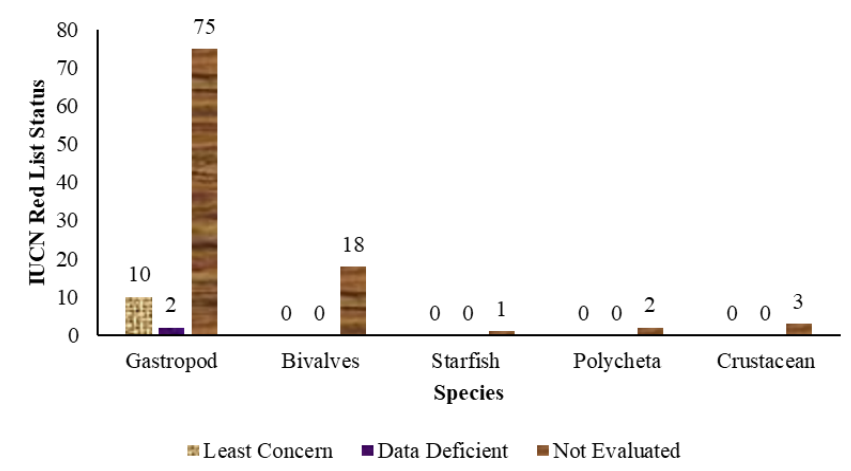

Figure 7. IUCN red list status of available species in PunangSari-Lawas River Estuary, Sarawak, Malaysia

\section{Discussion}

Macrobenthos fauna is essential organisms in the functioning of coastal and marine ecosystems, including seagrass and mangrove habitat, which play a significant role in the marine benthic food chain (Gerami et al. 2016). The number of gastropods, bivalve, echinoderm, polychaete, and crustacean was found in this present study, which can be considered as a checklist of faunal diversity in Punang-Sari, Lawas estuary at Sarawak, Malaysia. Previous studies by Matin et al. (2018) in Bangladesh coast; Wong and Arshad (2011) in Malaysia; Hamli et al. (2013) and Hamli et al. (2012) in Sarawak, Malaysia; Satumanatpan et al. (2011) at seagrass bed in Thailand and Zvonareva et al. (2019) in Vietnam were reported the similar checklist of present findings. Most of the members in family Neritidae are herbivorous except some freshwater species (Unabia 2011); in this present study, the highest 8 species of gastropods from Neritidae family were recorded in seagrass meadows of Punang-Sari, Lawas. These species were found on the top of the leaf of seagrass and graze for its basic nutrition and shelter. Another mostly available herbivorous family found in seagrass bed was Trochidae. Studies from the Mediterranean Sea revealed that some species from this family are highly associated with seagrass bed (Donnarumma et al. 2018). The present study revealed an abundant number of gastropods in the seagrass bed than the other parts of Malaysia (Azmi et al. 2019). Studies showed that seagrass and different bivalve species have facultative mutualism interaction in a habitat where bivalve excrete a healthy ratio of $\mathrm{C}: \mathrm{N}, \mathrm{N}: \mathrm{P}$, and $\mathrm{C}: \mathrm{P}$, which is essential micro-nutrients for seagrass beds. However, on return, seagrass sheltered bivalve from washed out, which is essential for survival in the intertidal zone of a coastal area (Peterson and Heck 2001). In the current investigation, the number of bivalve species recorded from seagrass habitats was lower than the study of Wong et al. (2014) from Straits of Malacca, Malaysia, and Cob et al. (2014) from Merambong Shoal, Malaysia. However, studies from the seagrass bed of Sungai Pulai, Johor, Malaysia by Idris et al. (2008) recorded two new species of bivalves, which is lower than the present study. Some studies indicated that seagrass beds are a safe place for different polychaete species (Susan et al. 2011; Mohamamad and Jalal 2018) although recorded polychaete species in this present study were only two.

Mangroves are considered most productive ecosystems on planet earth, lying at the boundary between land and sea in tropical and subtropical regions which supports genetically diverse groups of aquatic and terrestrial creatures that can adapt to exist under wide ranges ecological conditions (Kathiresan et al. 2015). Mangrove of Punang-Sari, Lawas estuary has sheltered different macrobenthic fauna including gastropod, bivalve, polychaete, and crustacean, which made this ecosystem very productive. Studies by Sunarto and Rahayu (2017) from Purworejo, Central Java, Indonesia revealed that mangrove habitat sheltered 34 species of fish, crustacean, gastropod, and bivalve, while current study was not dealt with fish species, but a large number of gastropods, bivalves, and crustaceans species were recorded from Punang-Sari, Lawas estuary, Sarawak. Previous studies in Southeast Asian mangrove habitats, for instance, Malaysia (Abu Hena et al. 2016), Vietnam (Zvonareva et al. 2019), Indonesia (Sunarto and Rahayu 2017), and Thailand (Premcharoen et al. 2016) also showed the similar community composition. However, several studies only focused on the crustacean population from the mangrove (Kunsook and Dumrongrojwatthana 2017). Therefore, new species of hermit crab (Genus: Coenobita) from Singapore, Malaysia, and Indonesia, which was previously confused with $C$. cavipes, these previous studies are similar to the present study. Benthic faunal assemblage in non-mangrove and seagrass zones highly depends on different limiting factors, for instance, grain size of soil, frequency of tidal actions, season, land elevation (Susan et al. 2014). The present study revealed, the macrobenthic bio-assemblage in NMS zone was lower compared to the seagrass and mangrove complex area. The recorded species in the current study were lesser than the studies by Tan and Yeo (2010), which found 252 species of benthic fauna from Pulau Semakau, Singapore.

In this present study, family Nassariidae was the dominant group, which had the highest number of species (13 species). Previous studies in Malaysia also reported that family Nassariidae was their most dominant family 
according to the number of species in their studies (Azmi et al. 2019). Some other studies from Thailand (Satumanatpan et al. 2011) and Indonesia (Dewiyanti and Karina 2012) also found Nassariidae as a dominant family in their study. Meanwhile, Cob et al. $(2012,2014)$ revealed that species from family Nassariidae are widespread in the seagrassmangrove complex along with the intertidal zone.

It was observed in the current study, Veneridae (6 species) was the most diverse bivalve group, which is similar compared to other studies in Malaysia by Hamli et al. (2012). Dominant Veneridae family is also back by the study of Dewiyanti and Karina (2012) from Aceh Besar and Banda Aceh districts, Indonesia, and studies of Satumanatpan et al. (2011) from Kung Krabaen Bay, Chantaburi Province, Thailand. Hamli et al. (2016) and Hamli et al. (2017) mentioned two different bivalves from Veneridae family in Sarawak, which is similar to the present study. Quiros et al. (2018) found Veneridae is one of the popular bivalve family captured by the fisher in Philippines. The species Cerithium atratum (Family: Cerithiidae), Ctenoides philippinarum (Family: Limidae), Diogenes sp., and Clibanarius longitarsus (Family: Paguroidea) were the most distributed species of gastropods, bivalvia, and polychaete respectively which were found in three study areas (seagrass, mangrove, and NMS). Some of the macrobenthic species found in PunangSari, Lawas estuary has commercial importance (Hamli et al. 2013), and some are ecologically important (Halim et al. 2019) which could be taken into aquaculture consideration and ecological conservation. Further ecological assessment and continuous monitoring of faunal assemblage in Punang-Sari estuary, Lawas, Sarawak, Malaysia is recommended.

Cluster analysis of benthos density in three habitats revealed a clear inter-habitat grouping. The dendrogram presented the macrobenthos density of all three habitats were generally classified into two groups at the similarity level of 10.5 (Euclidean) based on the difference of habitats (Figure 2). The cluster analysis revealed inter-habitat grouping, where three habitats were mainly classified into two groups at the similarity level of 10.5. Jaccard similarity index showed that seagrass and mangrove habitat was the most similar habitat in this present study. The highest family principal correlation factor was found in the seagrass area (0.96), and the lowest correlation factor was found in NMS sampling area (0.65). Seagrass habitat showed very assemble trend than other two habitats, and NMS habitat showed most dissimilarity of species which is very similar to the study of Marina et al. (2012). The IUCN red list status analysis revealed that ten species had accessed as least concern species, two had data deficient and rest has status (most of the species) did not evaluate yet. Similar studies conducted in a different part of the globe and suggest almost the same result (Peters et al. 2013 and Nicolai and Ansart 2017).

The present investigation revealed the record of 111 species of gastropod, bivalve, polychaete, echinoderm, and crab from the Punang-Sari estuary, Lawas, Sarawak, Malaysia. From which some species were commercially at the same time ecologically important. The species
Cerithium atratum (gastropod), Ctenoides philippinarum (bivalve), Diogenes sp. and Clibanarius longitarsus (polychaete) and Perinereis maindroni (Hermit crab) were the most distributed species found in the present study. Further assessment, ecological studies, and long-term monitoring of macrobenthic community in Punang-Sari estuary, Lawas, Sarawak, Malaysia can reveal the ecosystem characteristic of this seagrass-mangroveintertidal complex.

\section{ACKNOWLEDGEMENTS}

The authors would like to thank Universiti Putra Malaysia Bintulu Sarawak Campus for laboratory facilities and support during the entire period of study. We wish to thank Awangku Ahmad Nizam, Wan Mohamad Aiman, and Higher Education Malaysia FRGS research support; grant code, 07-01-18-2044FR.

\section{REFERENCES}

Abu Hena MK, Hishamuddin O, Misri K, Abdullah F, Loo KK. 2004. Benthic faunal composition of Penaeus monodon Fabricius culture pond on west coast of Peninsular Malaysia. J Biol Sci 4: 631-636. DOI: $10.3923 / j b s .2004 .631 .636$

Abu Hena MK, Idris MH, Khairul RMY, Bhuiyan MKA, Hoque N, Kumar U. 2016. Diversity of macro-benthos in the mangrove forest of Kuala Sibuti, Miri, Sarawak. Malaysia International Biology Symposium. Putrajaya International Convention Center, Putrajaya, October 2016.

Abu Hena MK, Idris MH, Rhemaneeta, A, Sinden A, Bhuiyan MKA. 2017. Soil carbon storage in selected mangrove forests of Sarawak, Malaysia. International Conference on Sustainable Soil Management. Bintulu, Sarawak, April 2017

Azmi NF, Ghaffar MA, Cob ZC. 2019. Apicomplexa-like parasites in some gastropods from Merambong seagrass bed, Johor Straits, Malaysia. Turkish J Fish Aqua Sci 19 (2): 89-97.

Bujang JS, Zakaria MH, Short FT. 2018. Seagrass in Malaysia: Issues and challenges ahead. In: Finlayson C, Milton G, Prentice R, Davidson N (eds). The Wetland Book. Springer, Dordrecht.

Chan SY. 2009. The Melongenidae (Mollusca: Gastropoda) of Singapore. Nat Singap 2: 63-67.

Chaouti A, Azirar A, Bayed A. 2019. Macrofaunal spatial distribution and community structure in a lagoon without a river discharge (the Oualidia lagoon, NW Morocco). Mar Ecol 40 (4): e12557. DOI: $10.1111 /$ maec. 12557

Cob ZC, Arshad A, Japar Sidik B, Ghaffar MA. 2014. Spatial and temporal variations in Strombus canarium (Gastropoda: Strombidae) abundance at Merambong seagrass bed, Malaysia. Sains Malaysiana 43 (4): 503-511.

Cob ZC, Samat A, Muda WMLW, Mazlan AG. 2012. Preliminary checklist of marine invertebrate fauna within the intertidal of Teluk Penyabong and Teluk Gorek, Mersing, Johor, Malaysia. J Trop Mar Ecosys 1 (2012): 1-14.

Dewiyanti I, Karina S. 2012. Diversity of gastropods and bivalves in mangrove ecosystem rehabilitation areas in Aceh Besar and Banda Aceh districts, Indonesia. AACL Bioflux 5 (2): 55-59.

Donnarumma L, Bruno R, Terlizzi A, Russo GF. 2018. Population ecology of Jujubinus striatus and Jujubinus exasperatus (Gastropoda: Trochidae) in a Posidonia oceanica seagrass bed. European Zool J 85 (1): 17-25. DOI: 10.1080/24750263.2017.1420828

Esenowo IK, Ugwumba AAA. 2010. Composition and abundance of macrobenthos in Majidun River, Ikorordu Lagos State, Nigeria. Res J Biol Sci 5 (8): 556-560.

Fairoz M, Rozaimi M, Nastasia WF. 2018. Records of sea star (Echinodermata, Asteroidea) diversity in a disturbed tropical seagrass meadow. Arxius Miscel Zool 16: 243-254 
Fortes MD. 1991. Seagrass-mangrove ecosystems management: A key to marine coastal conservation in the ASEAN region. Mar Poll Bull 23: 113-116. DOI: 10.1016/0025-326X(91)90659-G

Gerami MH, Patimar R, Negarestan H, Jafarian H, Mortazavi MS. 2015 Temporal variability in macroinvertebrates diversity patterns and their relation with environmental factors. Biodiversitas 17 (1): 36-43. DOI: 10.13057/biodiv/d170106

Halim SSA, Shuib S, Talib A, Yahya K. 2019. Species composition, richness, and distribution of molluscs from intertidal areas at Penang Island, Malaysia. Songklanakarin J Sci Tech 41 (1): 165-173.

Hamli H, Idris MH, Abu Hena MK, King WS. 2012. Diversity of edible Mollusc (Gastropoda and Bivalvia) at selected division of Sarawak, Malaysia. Int J Adv Sci Eng Info Tech 2 (4): 5-7.

Hamli H, Idris MH, Abu Hena MK, Rajaee AH, Arshad A. 2016. Inner shell as variation key of local hard clam Meretrix spp. J Env Biol 37 (4): 641-646.

Hamli H, Idris MH, Abu Hena MK, Wong SK, Arshad A. 2013. Checklist and habitat descriptions of edible gastropods from Sarawak, Malaysia. J Fish Aqua Sci 8 (2): 412-418.

Hamli H, Idris MH, Rajaee AH, Abu Hena MK, Hoque MN. 2017. Condition Index of Meretrix lyrata (Sowerby 1851) and its relationship with water parameter in Sarawak. Sains Malaysiana 46 (4): $545-551$.

Hamli H, Rahim AA, Idris MH, Abu Hena MK, King WS. 2015 Morphometric variation among three local mangrove clam species of Corbiculidae. Songklanakarin J Sci Tech 37 (1): 15-20.

Herbert DG, Jones GJ, Atkinson LJ. 2018. Phylum Mollusca. In: Atkinson LJ, Sink KJ (eds). Field Guide to the offshore Marine Invertebrates of South Africa. Malachite Marketing and Media, Pretoria.

Idris MH, Arshad A, Japar SB, Daud SK, Ghaffar MA. 2008. New distribution record of two pen shells (Bivalvia: Pinnidae) from the seagrass beds of Sungai Pulai, Johore, Malaysia. J Biol Sci 8 (5): 882 888.

Idris MH, Hamli H, Abu Hena MK, Rajaee AH. 2017b. Distribution of mineral contents in the selected tissues of Meretrix lyrata. J Fish Aqua Sci 12 (3): 149-156.

Idris MH, Rahim AA, Hamli H, Nesarul MH, Abu Hena MK. 2017a Determination of gonad development of mangrove clam Polymesoda expansa (Mousson 1849) by histological classification. J Fish Aqua Sci 12 (4): 168-176.

IUCN. 2020. The IUCN Red List of Threatened Species. Version 2019-3. www.iucnredlist.org

Jaccard P. 1901. Étude comparative de la distribution florale dans une portion des Alpes et des Jura". Bull de la Société Vaudoise des Sciences Naturelles 37 (142): 547-579. DOI: 10.5169/seals-266450

Kathiresan K, Veerappan N, Balasubramanian R. 2015. Status of fauna in mangrove ecosystems of India. In: Venkataraman K, Sivaperuman C (eds). Marine Faunal Diversity in India. Elsevier, Amsterdam.

Kunsook C, Dumrongrojwatthana P. 2017. Species diversity and abundance of marine crabs (Portunidae: Decapoda) from a collapsible crab trap fishery at Kung Krabaen Bay, Chanthaburi Province, Thailand. Trop Life Sci Res 28 (1): 45-67. DOI: 10.21315/tlsr2017.28.1.4

Marina P, Urra J, Rueda JL, Salas C. 2012. Composition and structure of the molluscan assemblage associated with a Cymodocea nodosa bed in south-eastern Spain: Seasonal and diel variation. Helgoland Mar Res 66 (4): 585-599. DOI: 10.1007/s10152-012-0294-3

Matin A, Hossain MB, Iqbal M, Billah MM, Asif AA, Billah MM. 2018 Diversity and abundance of Macrobenthos in a subtropical estuary, Bangladesh. Species 19: 140-150.

Mendoza ARR, Patalinghug JMR, Divinagracia JY. 2019. The benefit of one cannot replace the other: Seagrass and mangrove ecosystems at Santa Fe, Bantayan Island. J Ecol Environ 43: 18. DOI: 10.1186/s41610-019-0114-7.

Mohamamad A, Jalal KCA. 2018. Macrobenthic diversity and community composition in the Pahang estuary, Malaysia. J Coast Res 82: 206211. DOI: $10.2112 /$ SI82-030.1.

Ng TH, Dulipat J, Foon JK, Lopes-Lima M, Zieritz A, Liew TS. 2017. A preliminary checklist of the freshwater snails of Sabah (Malaysian Borneo) deposited in the Borneensis collection (Universiti Malaysia Sabah). ZooKeys 673: 105-123. DOI: 10.3897/zookeys.673.12544

Nicolai A, Ansart A. 2017. Conservation at a slow pace: terrestrial gastropods facing fast-changing climate. Conserv Physiol 5 (1): 1-17. DOI: 10.1093/conphys/cox007

Ortega I, Colling LA, Dumont LFC. 2018. Response of soft-bottom macrobenthic assemblages to artisanal trawling fisheries in a subtropical estuary. Est Coast Shelf Sci 207: 142-153. DOI: 10.1016/j.ecss.2018.04.007

Pearson K. 1901. On lines and planes of closest fit to systems of points in space. Philos Magaz 2: 559-572. DOI: 10.1080/14786440109462720

Peters H, O'Leary BC, Hawkins JP, Carpenter KE, Roberts CM. 2013. Conus: First comprehensive conservation red list assessment of a marine gastropod Mollusc genus. PLoS ONE 8: e83353. DOI: 10.1371/journal.pone.0083353

Peterson BJ, Heck KL. 2001. Positive interactions between suspensionfeeding bivalves and seagrass- a facultative mutualism. Mar Ecol Prog Ser 213: 143-155. DOI: 10.3354/meps213143

Poutiers M. 1998. The living marine resources of the Western central Pacific. In: Carpenter KE, Niem VH (eds). FAO Species Identification Guide for Fishery Purpose. Food and Agriculture Organization of the United Nations, Rome.

Premcharoen S, Witirawat S, Tharapoom P. 2016. Molluscan fauna in Bang Taboon mangrove estuary, inner Gulf of Thailand: Implications for conservation and sustainable use of coastal resources. MATEC Web Conf 60: 02003. DOI: 10.1051/matecconf/20166002003

Qingxi H, Qinggong H, Junyong Z, Qiuying H. 2017. Macrobenthic assemblages across a gradient of seagrass habitat in Swan Lake, China. Intl J Oceans Oceanogr 11 (1): 45-62

Quiros TEAL, Beck MW, Araw A, Croll DA, Tershy B. 2018. Smallscale seagrass fisheries can reduce social vulnerability: A comparative case study. Ocean Coast Man 157: 56-67. DOI: 10.1016/j.ocecoaman.2018.02.003

Rezek RJ, Lebreton B, Sterba-Boatwright B, Beseres PJ. 2017. Ecological structure and function in a restored versus natural salt marsh. PLoS ONE 12: e0189871. DOI: 10.1371/journal.pone.0189871

Saenger P, Gartside D, Funge-Smith S. 2012. A review of mangrove and seagrass ecosystems and their linkage to fisheries and fisheries management. RAP Publication, Bangkok.

Satumanatpan S, Thummikkapong S, Kanongdate K. 2011. Biodiversity of benthic fauna in the seagrass ecosystem of Kung Krabaen Bay, Chantaburi province, Thailand. Songklanakarin J Sci Tech 33 (3): 341-348.

Sea Life Base. 2020. In: Palomares MLD, Pauly D (eds). World Wide Web Electronic Publication. www.sealifebase.org. version $(02 / 2020)$.

Short FT, Polidoro B, Livingstone SR, Carpenter KE, Bandeira S, Bujang JS, Calumpong HP, Carruthers TJB, Coles RG, Dennison WC, Erftemeijer PLA, Fortes MD, Freeman AS, Jagtap TG, Abu Hena MK, Kendrick GA, Kenworthy WJ, Nafie YAL, Nasution IM, Orth RJ, Prathep A, Sanciangco JC, Tussenbroek B, Vergara SG, Waycott M, Zieman JC. 2011. Extinction risk assessment of the world's seagrass species. Biol Conserv 144 (7): 1961-1971. DOI: 10.1016/j.biocon.2011.04.010

Singh HR, Baharin NK. 2016. Gastropod community structure from varying levels of mangrove disturbance in Selangor, Malaysia. Malays For 79: 54-63.

Sunarto W, Rahayu SM. 2017. Biodiversity of mangrove aquatic fauna in Purworejo, Central Java, Indonesia. Biodiversitas 18 (4): 1344-1352. DOI: 10.13057/biodiv/d180309

Susan VD, Pillai NGK, Satheeshkumar P. 2011. New polychaete records from seagrass beds at Minicoy Island, Lakshadweep, India. Ocean Sci J 46 (4): 315-321

Susan VD, SatheeshKumar P, Pillai NGK. 2014. Biodiversity and seasonal variation of benthic macrofauna in Minicoy Island, Lakshadweep, India. Acta Ocean Sin 33 (10): 5873. DOI: $10.1007 / \mathrm{s} 13131-014-0541-3$

Tan SK, Clements R. 2008. Taxonomy and distribution of the Neritidae (Mollusca: Gastropoda) in Singapore. Zool Stud 47 (4): 481-494.

Tan SK, Yeo RKH. 2010. The intertidal Molluscs of Pulau Semakau: Preliminary results of "Project Semakau". Nat Singap 3: 287-296.

Unabia CRC. 2011. The snail Smaragdia bryanae (Neritopsina, Neritidae) is a specialist herbivore of the seagrass Halophila hawaiiana (Alismatidae, Hydrocharitaceae). Invert Biol 130 (2): 100-114. DOI: 10.1111/j.1744-7410.2011.00225.x

Valenca APMC, Santos PJP. 2013. Macrobenthic community structure in tropical estuaries: the effect of sieve mesh-size and sampling depth on estimated abundance, biomass and composition. J Mar Biol Assoc UK 93 (6): 1441-1456.

Wong HW. 2009. The Mactridae of east coast Park, Singapore. Nat Sing 2: 283-296.

Wong NLWS, Arshad A, Yusoff FM, Japar Sidik B, Mazlan AG. 2014 The epifaunal marine bivalves and macrophytes in Merambong Shoal, 
Pulai River Estuary, Straits of Malacca. Malayan Nat J 66 (1 and 2): 42-51.

Wong NLWS, Arshad A. 2011. A brief review on marine shelled mollusca (Gastropoda and Bivalvia) record in Malaysia. J Fish Aqua Sci 6 (7) 669-699.
WoRMS EB. 2020. World Register of Marine Species. ww.marinespecies.org/.

Zvonareva SS, Mekhova ES, Hà VT, Kantor YI. 2019. Checklist of bivalve Molluscs in mangroves of Khánh Hòa Province, Vietnam. Moll Res 39: 1-17. DOI: 10.1080/13235818.2019.1638567. 